\title{
TSTA3 Gene
}

National Cancer Institute

\section{Source}

National Cancer Institute. TSTA3 Gene. NCI Thesaurus. Code C156967.

This gene is involved in mannose metabolism. 